University of Nebraska - Lincoln

DigitalCommons@University of Nebraska - Lincoln

Journal for the Advancement of Developing

Economies

Economics Department

2016

Motivations for Luxury Consumption: Insights from Tunisia's

Emerging Market

Pranjal Gupta,

University of Tampa, pgupta@ut.edu

Mouna Zaghdoudi

University of Tampa

Follow this and additional works at: https://digitalcommons.unl.edu/jade

Part of the Econometrics Commons, Growth and Development Commons, International Economics

Commons, Political Economy Commons, Public Economics Commons, and the Regional Economics

Commons

Gupta,, Pranjal and Zaghdoudi, Mouna, "Motivations for Luxury Consumption: Insights from Tunisia's Emerging Market" (2016). Journal for the Advancement of Developing Economies. 2.

https://digitalcommons.unl.edu/jade/2

This Article is brought to you for free and open access by the Economics Department at DigitalCommons@University of Nebraska - Lincoln. It has been accepted for inclusion in Journal for the Advancement of Developing Economies by an authorized administrator of DigitalCommons@University of Nebraska - Lincoln. 


\title{
Motivations for Luxury Consumption: Insights from Tunisia's Emerging Market
}

\author{
Pranjal Gupta, Mouna Zaghdoudi, \\ Sykes College of Business, University of Tampa
}

\begin{abstract}
Luxury consumption and the desire for luxury are well-accepted phenomena. Myriad studies have documented the pervasiveness of the luxury market in the West and the high growth and strong potential of Asian luxury markets. It is also evident that as resources have grown in a region, luxury consumption and the desire for luxury products have followed. Nevertheless, the need for more farreaching studies that explore emerging markets are important to understand the differences in how luxury may penetrate these markets, given variations in resources and culture. This paper investigates a number of factors that may contribute to the emergence of new luxury markets. Specifically, the authors focus on the psychology of luxury consumption in the post-revolution Tunisian market. In particular, this research attempts to understand the psychology behind the consumption of luxury items in Tunisia and provide managerial insights into strategies for entry into such emerging markets. The empirical data was collected using online surveys of participants from French-speaking Tunisia. Overall, this analysis of the Tunisian market for branded products and services informs international luxury managers in developing their strategies to penetrate emerging markets. Besides the managerial insights that the results provide, the hypotheses tested in this paper relating luxury consumption to the variables of age, income, and education within the framework of national culture are important contributions from the theoretical standpoint.
\end{abstract}

Keywords: Tunisia, Luxury Goods, Consumption and Luxury, Emerging Markets, Culture and Consumption, Demographics and Luxury Consumption.

\section{INTRODUCTION}

Throughout history, Tunisia has been a civilization of different people. Multiple successive dynasties and civilizations settled in Tunisia in the past included Carthaginian, Roman, Andalusian, Ottoman, Vandal, Jewish, Christian, Arab, Islamic, Turkish, French and native Berbers. This intermingling of people occurred in a geographical location nestled between the Mediterranean, African and Arab worlds. This mosaic of cultures and myriad influences gave birth to an educated, open-minded, Europeanized, fashion-driven and relatively well-to-do society willing to give up large amounts of money to acquire luxury products.

It is not altogether surprising for such a nation to be the one that triggered one of the most important turning points in world history: the Arab Spring. The Arab Spring refers to the democratic uprisings that started in Tunisia in December 2010 and spread all over the Arab world. Several studies (AlMomani 2011; Bishku 2013; Dadush \& Dunne 2011; Dziri 2013; Maddy-Weitzman 2011; Martin 2011; Sanchez 2009) have been conducted to assess the post- revolution economic and political 
health of Tunisia and to evaluate new investment opportunities. However, relatively little research has focused on the luxury goods industry, and even fewer studies have examined luxury consumption behavior of the Tunisian population from a cultural or psychological standpoint. Therefore, the overall objective of this study is to explore and test theory pertaining to luxury consumption in the emerging market that Tunisia represents. Given the diverse cultural heritage and interaction that Tunisia has had with Europe, Africa and the Middle East, the luxury consumption behaviors found here will likely be similar in educated, emerging economies that are exposed to and interact with developed economies through television, social media and the Internet.

\section{LITERATURE REVIEW}

The following literature review briefly outlines the political and socio-economic conditions of Tunisia to understand the viability of the luxury market under such conditions. Further, theory pertaining to understanding key determinants of luxury product desire and consumption, from the psychological and cultural perspectives, will be discussed.

\section{The Socio-Economic Context of Tunisia}

Tunisia has been known throughout history as an open Mediterranean trading country. Prior to the revolution, the Tunisian economy was healthy on a macroeconomic level: low inflation rate, sufficient currency reserves, acceptable budget deficits, and annual rates of growth of 5 percent or higher. However, Tunisia still suffers from problems such as overreliance on agriculture, weakness in the private sector, and high rates of unemployment, especially among the young (MaddyWeitzman 2011). Despite these challenges, the modernization that was put into place after independence from being a French protectorate in 1956 has generated significant positives that have led to stronger economic potential. For example, unlike other Arab countries, Tunisia has banned polygamy. As a result, the majority of women enjoy higher social status and better economic conditions. Furthermore, Tunisia has had a lower rate of population growth compared to the rest of the Arab world, has an active civil society backed by labor unions, a non-politicized military (Maddy-Weitzman 2011) and an educated workforce (Sanchez 2009). Tunisia is designated as a lower middle income country with a gross national income per capita of about $\$ 4,000$ (The World Bank, n.d.). However, the middle $60 \%$ of the population enjoys about $50 \%$ share of all income, suggesting a growing middle income group (The World Bank, n.d.). All these factors play a pivotal role in the shaping consumption of luxury products in post-revolutionary Tunisia.

\section{Post-Revolution Tunisia}

Even prior to the Revolution, Tunisia's geographic location and openness had attracted six and a half million tourists annually (Sanchez 2009). Tunisia has always maintained good diplomatic, political, and economic relations with the Western developed world. Free exchange of goods, services, and human capital between the United States, other western countries, and the region, create investments and subsequently job opportunities (Martin 2012). Examples of large American corporations investing in Tunisia are Fidelity Investments and IBM, which opened new regional headquarters in the capital city of Tunis very recently (Martin 2012).

From the socio-political perspective, the first elected government, despite being led by an Islamist party, opposed the institution of sharia Islamic Law in the constitution and the bans of alcohol and payment of interest. Such a stance reassured Tunisian secularists, potential foreign investors, and 
tourists of Tunisia's openness to foreign economic participation (Bishku 2013). Despite the numerous threats to stability, the Arab world, in general, is embracing a new era of economic, political, and social development (Al-Momani 2011). Tunisia, in particular, seems to be the most promising country among all the post-revolutionary countries. The World Economic Forum in its Global Competitiveness Report of 2006-2007 described the Tunisian economy as the most competitive in Africa and in the Arab world (Sanchez 2009). Furthermore, the Tunisian population is more literate and less impoverished than other Arab countries, has a stronger middle class than most other nations, and possesses government that has spurred private foreign investment in industry (Bishku 2013). Thus, despite Africa commanding only about 2\% of the worldwide luxury products market (Statista, n.d.), Tunisia serves as an excellent market to study how the luxury industry may penetrate emerging and opening markets

Against this backdrop, this research aims to explore and test theory associated with luxury consumption in the Tunisian market. Given the relative openness of the government to foreign economic participation, and a stronger middle class with more exposure to foreign ideas, products, and brands, studying Tunisian consumer behavior with regards to luxury products is timely and pertinent. The insights from Tunisian consumers are likely to reflect the desires for luxury products in other emerging markets.

\section{THEORY AND HYPOTHESIS}

In recent years, the world market for luxury goods has experienced significant growth, from being valued at $\$ 60$ billion in 1990 to about $\$ 240$ billion in 2015 (Le Monkhouse, Barnes \& Stephan 2012). Although the desire amongst the well-heeled to enjoy high quality products from the functional or the social conspicuousness perspectives has been known for a long time, recent evidence suggests that increasing number of markets with limited financial resources are demanding luxury goods much more than before (Souiden, M'Saad, \& Pons 2011). It seems reasonable to attribute some of this phenomenal growth in the luxury product market to consumer desire created by significantly enhanced awareness and information sharing about luxury products across the world. The proliferation of the Internet has likely had a significant role in creating rapid awareness of luxury products and services. Today, observing celebrities, brand advertising, and lay people consuming luxury products in different societies across the world has become restricted not by location, but by Internet connectivity. It is not surprising, therefore, that consumers in the developing world now show very similar interests in branded fashion accessories compared to their counterparts in the developed world (Suiden, M'Saad and Pons 2011). This trend is observed particularly in emerging countries like Brazil, India, and China, where the luxury market growth rates range from $20 \%$ to $35 \%$, boosted by both affluent customers and less affluent social status seekers who purchase luxury brands (Souiden, M'Saad, \& Pons 2011). Mass marketing of luxury goods (Souiden, M'Saad, \& Pons 2011) is now part of the luxury product landscape. It is, in fact, not surprising that an increasing number of luxury manufacturers are trying to make their products affordable to a wider range of people by adding lower-priced items to their product lines. On the same line of reasoning, Soyoung and Jongeun (2011) introduced the "masstige" concept, which refers to "mass" prestige. Masstige products are defined as "premium but attainable," and are considered luxury or premium products that have been priced to be attainable to the middle classes. In fact, with the growing number of middle class consumers who are willing to spend large 
percentages of their income on luxury products, luxury producers are expanding their narrow circle of ultra-affluent consumers to include the willing middle class.

An important factor that has strongly supported the remarkable luxury product penetration in Asia is their culture (Soyoung \& Jongeun 2011). In particular, most Asian nations tend to be high on power distance and collectivism (Hofstede 2001). Maintenance of power distances usually leads to a choice of products that accentuate those differences. For instance, a manager attaining a certain post may feel compelled or be urged to consume certain types of products to conform. Furthermore, collectivism is likely to lead consumers to choose products that help them fit into a variety of social groups, or to achieve conformity in their aspirant groups (Soyoung \& Jongeun 2011). Interestingly, country comparisons between Middle Eastern and Asian countries reveal a striking similarity in terms of these two key dimensions (Hofstede 2001). Thus, it is very likely that consumers in emerging markets like Tunisia will exhibit attitudes towards luxury products very similar to the attitudes of their Asian counterparts. Thus, from the cultural perspective, over time Tunisian consumers are likely to seek and consume luxury products in a manner similar to Asian consumers.

However, it is imperative to explore the boundary conditions of such a generalized propensity towards luxury product consumption and desire. Certainly, the lure of luxury products from the quality and enhanced functionality perspectives is very reasonable. However, conspicuous consumption of products is often done to display wealth and social status or to seek social acceptance. Purchasing luxury products often has customers perceiving themselves as being in higher status positions in society, which elicits feelings of pleasure, excitement and confidence (Lim, Ting, Khoo \& Wong 2012). Although conspicuous consumption is a fairly universal phenomenon it is likely more pervasive in more collectivist and high power distance countries, including those in Asia and the Middle East. Very often, conspicuous consumption has a role to play in fostering materialism (Hanzaee \& Rouhani 2013), which is the importance a consumer attaches to worldly possessions (Hudders \& Pandelaere 2011). Materialism values publicly consumed goods more than privately consumed ones. Susceptibility to the need for conformity, a hallmark of collectivist and high power distance societies, has been considered one of the most significant factors influencing the need for publicly consumed products. Conformity has been shown to significantly impact the purchasing of foreign luxury brands (Park, Rabolt \& Jeon 2008). Therefore, one likely motivation of materialism is the use of possessions and consumer goods to communicate an individual's personal identity, social class, or status.

Therefore, from the cultural perspective, we would expect that Tunisian consumers will exhibit a significant desire for luxury products to enable expression of social position. However, to the extent younger consumers are more exposed to media and information, and have a stronger need to conform to social groups, it is very likely that this desire for luxury products will be stronger for younger consumers in the Tunisian market. Thus, we hypothesize:

H1a: The desire for luxury products is stronger for younger compared to older consumers. 
Next, younger consumers are likely to be less prudent compared to older consumers. Also, with relatively less income, they are more likely to spend somewhat more recklessly on luxury products. Therefore,

H1b: The proportion of income spent on luxury is higher for younger compared to older consumers.

Next, as consumers grow in age, they are likely to gain in prudence and are less likely to be subject to norm based pressures than their younger counterparts. The ability to make self- determined choices, albeit for luxury products, is likely to be stronger for older consumers. In other words, public consumption, and therefore the approval of others, will be stronger for younger consumers compared to older buyers.

H1c: Opinions of others in relation to product purchases is more important for younger compared to older consumers.

Lastly, younger consumers, who are more susceptible to social pressure to engage in conspicuous consumption to fulfill social expectations, are more likely to hold the views that materialism and socially inspired consumption are prevalent in their society. Thus,

H1d: The belief about the prevalence of materialism in society is stronger for younger compared to older consumers.

H1e: The belief that other consumers purchase luxury products largely to display to others is stronger for younger compared to older consumers.

Another important variable explored in this study is the formal education levels of consumers. The fundamental premise is that as education increases, the sense of independence and selfdetermination is likely to rise as well. It is therefore likely that the felt social impositions and cultural norms to conform will be less intensely felt for more educated consumers. Thus, it is reasonable to expect that when engaging in luxury consumption that is more determined by social or cultural pressures, consumers would probably also have less control over choices and, therefore, prices. On average, we expect that less educated consumers will spend what is required to acquire the product and be less price sensitive. On the other hand, more educated consumers will buy what they choose themselves based on personal criteria and will correspondingly spend with some restraint. Therefore, we propose,

H2a: The proportion of income spent on luxury is higher for less educated compared to more educated consumers.

$\mathrm{H} 2 \mathrm{~b}$ : The willingness to purchase luxury even if their existing debt level was higher than usual is higher for less educated compared to higher educated consumers

As discussed, education is likely to create a dichotomy whereby the desire for luxury products will stem from different reasons. A framework that is particularly useful to explore the differences in luxury product desire based on educational levels is one proposed by Le Monkhouse, Barnes \& 
Stephan (2012). Broadly, they propose that the key reasons for the desire for luxury are either conformity based consumption behaviors or self-indulgent, hedonistic forms of behavior. That is, besides purchasing luxury products for social conformity or public status display purposes, consumers may seek to purchase luxury products due predominantly to the high quality of the products. The quality they seek may include materials, design, technology, sophistication, utility and craftsmanship. Further, besides quality, another private reason for luxury product desire may be purely hedonism, or self-indulgence. Consumers may seek such products to enjoy or reward themselves with the sensory pleasures of well-performing and aesthetically pleasing luxury products. These would represent the "private" reasons for consumption. On the other hand, as discussed above, consumers may desire luxury to signal wealth, power, or social presentation (Demirbag, Sahadev \& Mellahi 2010). As an extension of the conspicuous value of luxury products, unique or exclusive products may also be used to portray dominant status and create distance with other consumers (Lim, Ting, Khoo \& Wong (2012), Melika Husic and Muris Cicic (2009)). These reasons form a subset of "public" reasons for luxury product consumption. It is likely that less educated consumers will be more susceptible to the "public" reasons for consumption of luxury products. On the other hand, educated consumers are correspondingly more likely to seek products more for "private" reasons, given their interest and ability to critically evaluate social and cultural norms and perhaps defy them. Therefore,

H2c: Luxury products with enduring, rather than temporary, style are chosen more by higher educated compared to lower educated consumers.

H2d: Luxury product purchases for the purpose of appearance enhancement will be made more by lower educated compared to higher educated consumers.

The next few hypotheses pertain to the impact of income on luxury consumption. To the extent income is a limiting factor, it is reasonable to expect that,

$\mathrm{H} 3 \mathrm{a}$ : The proportion of consumers in possession of luxury products will be higher for high income compared to low income consumers.

$\mathrm{H} 3 \mathrm{~b}$ : Amongst those without luxury products, the proportion of consumers willing purchase luxury products will be higher for high income compared to low income consumers.

However, to the extent luxury products costs are significant, lower income consumers are more likely to be willing to spend proportionally more to acquire such products, we expect that,

H3c: The willingness to spend a higher proportion of income on luxury products will be higher for low income compared to high income consumers.

Further, with very relatively few other markers of success in their lives, luxury products will represent success more to lower income consumers. On the other hand, higher income consumers are likely to be less inclined to see luxury products as mere expressions of success, particularly for 
conspicuous display. On the contrary, higher income consumers are more likely to seek luxury for "private" reasons such as hedonistic, or self-indulgent, reasons. Hence, we propose,

H3d: The tendency to view luxury products as an expression of accomplishment will be higher for low income compared to high income consumers.

H3e: The desire for luxury products to seek the best available products for themselves is stronger for higher income compared to lower income consumers.

H3f: The desire for luxury products to seek the best quality products for themselves is stronger for higher income compared to lower income consumers.

\section{METHODOLOGY}

The sample respondents were drawn exclusively from Tunisian Facebook users. One of the authors used her personal friends and family members as "seed" respondents and requested that each of them further forward the survey to at least five more friends or family members. The survey was conducted through Survey Monkey. Records were identified by name and date of birth to ensure no duplication of respondents in the database. The questionnaire was administered in both French and English. A Tunisian certified translator was asked to translate the questionnaire in order to ensure the accuracy and the correctness of the translation. Table 1 provides a summary of the demographics of the collected sample that used to test the hypotheses.

Table 1: Demographics of Sample Group

\begin{tabular}{|c|c|c|c|c|}
\hline $\begin{array}{l}\text { Sample } \\
\text { Size }\end{array}$ & Gender & Age & $\begin{array}{l}\text { Annual Income in } \\
\text { US Dollars* }\end{array}$ & Education \\
\hline 200 & $\begin{array}{l}\text { Males }(75,37.5 \%) \\
\text { Females }(125,62.5 \%)\end{array}$ & $\begin{array}{l}18-25(82,41 \%) \\
26-35(75,37.5 \%) \\
36-45(21,10.5 \%) \\
46-55(15,7.5 \%) \\
>55(7,3.5 \%)\end{array}$ & $\begin{array}{l}\$ 0-2275(61,30.5 \%) \\
\$ 2275-4550(37,18.5 \%) \\
\$ 4550-11375(69,34.5 \%) \\
>\$ 11375(33,16.5 \%)\end{array}$ & $\begin{array}{l}\text { High School }(23,11.5 \%) \\
\text { Bachelors }(48,24 \%) \\
\text { Masters }(76,38 \%) \\
\text { Doctorate }(39,19.5 \%)\end{array}$ \\
\hline
\end{tabular}

*In the survey, income was reported in Tunisian Dinars (TND), 0-5000, 5000-10000, 10000- 30000 and 30000 and above.

We corroborated the sample demographics with the population demographics. In terms of gender, the sample data is somewhat imbalanced towards women, perhaps because of the restriction to Facebook users (as a method of initial contact). In terms of age, the population demographics report about $38 \%$ to be less than 24 years of age, about $52 \%$ being in the age range $25-64$ and $8 \%$ over 65 years of age (The World Factbook, n.d.). The sample age statistics of $41 \%$ below 25 years of age, $55 \%$ between $26-55$ and about $4 \%$ over 55 seem reasonably matched with the population statistics. With a national literacy rate of about $82 \%$ (The World Factbook, n.d.), the sample's educational levels, where more than $62 \%$ have bachelors or masters degrees, seems appropriate. However, since 
Facebook was used to invite study participants, the sample certainly has more educated consumers than the national population. The distribution between the other categories was well balanced. In terms of income levels, four categories of income were used, measured in annual income. The median income of Tunisians was included as one of the middle categories. Here as well, the sample was well distributed with at least 30 respondents in each of the 4 categories of income measured. However, although reasonably representative, the sample has limitations, which are discussed in the Conclusions, Limitations and Future Directions section.

In the first section of the questionnaire, respondents answered questions related to demographic variables such as age, gender, marital status, education, occupation, country, and city of residence and annual income. Next, the questionnaire started with an introduction and examples of luxury brands (e.g., Louis Vuitton, Burberry, Dior, Chanel), and a yes or no screener question asking $(\mathrm{Y} / \mathrm{N})$ if the respondent owned at least one luxury brand. This determined eligibility to participate in the survey. Those that answered "No" were asked about their willingness to purchase luxury in the future. Next, respondents were asked to indicate at least two types of luxury products or services they prefer, and their brand names (e.g., Louis Vuitton purse, Louboutin shoes). The main purpose of this was to help respondents recall certain brands, as well as to ensure that they referred to luxury brands as defined in the survey and not to other fashion products such as Forever 21 or H\&M. Then, respondents were asked to indicate their degree of agreement and disagreement on a battery of items that were measured on a 10-point Likert scale, ranging from (1) strongly disagree to (10) strongly agree. All questions were single item questions developed by the authors and written very closely to match each hypothesis. For example, H2d hypothesizes that luxury is more often used to enhance appearance by less educated consumers than by more educated consumers. The question used to test this hypothesis simply asked respondents their level of agreement with the statement "Luxury products improve my appearance." All other questions are presented in Table 2. Finally, participants had to answer a number of open-ended questions concerning their consumption behavior. In order to ensure the anonymity of the participants and confidentiality of the data they provided, the questionnaire did not ask for information that could readily identify the participants, such as name or national identification number. The next section details the hypotheses testing, the measures used, and the results.

\section{RESULTS}

This section explores the results of the hypotheses testing. A summary of the hypotheses testing is provided in Table 2. Hypothesis 1 explores the relationships between age and consumption of luxury products in Tunisia. Broadly, theory suggests that the desire for and consumption of luxury products is a pervasive phenomenon across ages in virtually all cultures. Not surprisingly, even in the Tunisian market, the results are the same. More than $70 \%$ of our respondents reported owning at least one luxury item. The older age groups reported even higher penetration rates of luxury product ownership. Despite widespread ownership of luxury products across age categories, Hypothesis 1 explores the nuanced behaviors and attitudes towards luxury consumptions across different age groups. 
Table 2: Results of Hypotheses Testing

\begin{tabular}{|c|c|c|c|}
\hline Hypothesis & Relationshp Tested & Measures & Support \\
\hline 1(a) & -Age $\rightarrow+$ Luxury Desire & $\begin{array}{l}\text { IV: Age Categories, *DV: Are you willing } \\
\text { to buy a luxury product? (FOR THOSE } \\
\text { WHO DID NOT ALREADY HAVE } \\
\text { LUXURY PRODUCTS) }\end{array}$ & Yes; $p<0.03$ \\
\hline 1(b) & $\begin{array}{l}- \text { Age } \rightarrow+\text { Percentage } \\
\text { Income Spent on Luxury }\end{array}$ & $\begin{array}{l}\text { IV: Age Categories, *DV: What } \\
\text { percentage of your annual income do you } \\
\text { spend on luxury products? }\end{array}$ & Yes; $p<0.00$ \\
\hline $1(\mathrm{c})$ & $\begin{array}{l}\text {-Age } \rightarrow+\text { Importance of } \\
\text { Others' Opinions }\end{array}$ & $\begin{array}{l}\text { IV: Age Categories, ^ DV: When buying a } \\
\text { luxury product, other peoples' opinions } \\
\text { are important to me. }\end{array}$ & Yes; $\mathrm{p}<0.07$ \\
\hline $1(d)$ & $\begin{array}{l}\text {-Age } \rightarrow+\text { Belief about } \\
\text { societal materialism }\end{array}$ & $\begin{array}{l}\text { IV: Age Categories, }{ }^{\wedge} \mathrm{DV}: \text { Tunisians are } \\
\text { materialistic. }\end{array}$ & Yes; $p<0.06$ \\
\hline $1(\mathrm{e})$ & $\begin{array}{l}- \text { Age } \rightarrow+\text { Belief that } \\
\text { luxury is purchased for } \\
\text { display to others. }\end{array}$ & $\begin{array}{l}\text { IV: Age Categories, ^ DV: Tunisians } \\
\text { purchase luxury products and services to } \\
\text { show off. }\end{array}$ & No \\
\hline 2(a) & $\begin{array}{l}\text {-Education } \rightarrow+ \\
\text { Proportion of Income } \\
\text { Spent on Luxury }\end{array}$ & $\begin{array}{l}\text { IV: Education Categories, }{ }^{\wedge} \mathrm{DV}: \text { What } \\
\text { percentage of your annual income do you } \\
\text { spend on luxury products? }\end{array}$ & Yes, $\mathrm{p}<0.08$ \\
\hline 2(b) & $\begin{array}{l}\text {-Education } \rightarrow+ \\
\text { Willingness to accept } \\
\text { higher than usual debt } \\
\text { level for luxury }\end{array}$ & $\begin{array}{l}\text { IV: Education Categories, }{ }^{\wedge} \mathrm{DV} \text { : I would } \\
\text { not buy a luxury item if I felt that my debt } \\
\text { level is higher than usual. }\end{array}$ & Yes, $\mathrm{p}<0.02$ \\
\hline $2(\mathrm{c})$ & $\begin{array}{l}+ \text { Education } \rightarrow+ \\
\text { Purchased luxury will } \\
\text { have enduring style and } \\
\text { value }\end{array}$ & $\begin{array}{l}\text { IV: Education Categories, }{ }^{\wedge} \mathrm{DV} \text { : I select } \\
\text { luxury items that will have enduring style } \\
\text { and are therefore worth the investment }\end{array}$ & Yes, $\mathrm{p}<0.00$ \\
\hline $2(d)$ & $\begin{array}{l}\text {-Education } \rightarrow+\text { Luxury } \\
\text { use for appearance } \\
\text { enhancement }\end{array}$ & $\begin{array}{l}\text { IV: Education Categories, }{ }^{\wedge} \mathrm{DV}: \text { Luxury } \\
\text { products improve my appearance. }\end{array}$ & Yes, $\mathrm{p}<0.05$ \\
\hline $3(\mathrm{a})$ & $\begin{array}{l}+ \text { Income } \rightarrow+\text { Proportion } \\
\text { of persons with luxury } \\
\text { products }\end{array}$ & $\begin{array}{l}\text { IV: Income Categories, *DV: Are you in } \\
\text { possession of at least one luxury brand? }\end{array}$ & No \\
\hline $3(\mathrm{~b})$ & $\begin{array}{l}+ \text { Income } \rightarrow+\text { Proportion } \\
\text { of persons without luxury } \\
\text { willing to buy luxury }\end{array}$ & $\begin{array}{l}\text { IV: Income Categories, *DV: Are you } \\
\text { willing to buy a luxury product in the } \\
\text { future? }\end{array}$ & No \\
\hline $3(\mathrm{c})$ & $\begin{array}{l}\text {-Income } \rightarrow+\text { Proportion } \\
\text { of income spent on } \\
\text { luxury products }\end{array}$ & $\begin{array}{l}\text { IV: Income Categories, *DV: What } \\
\text { percentage of your annual income do you } \\
\text { spend on luxury products? }\end{array}$ & Yes, $\mathrm{p}<0.01$ \\
\hline $3(d)$ & $\begin{array}{l}\text {-Income } \rightarrow+\text { Tendency } \\
\text { to view luxury products } \\
\text { as accomplishment }\end{array}$ & $\begin{array}{l}\text { IV: Income Categories, }{ }^{\wedge} \mathrm{DV} \text { : Wearing } \\
\text { luxury apparel conveys that I am } \\
\text { accomplished and successful. }\end{array}$ & No \\
\hline $3(\mathrm{e})$ & $\begin{array}{l}\text { +Income } \rightarrow+\text { Desire to } \\
\text { seek the best available } \\
\text { luxury products }\end{array}$ & $\begin{array}{l}\text { IV: Income Categories, }{ }^{\wedge} \mathrm{DV}: \text { I want the } \\
\text { best of everything and for me that means } \\
\text { luxury brands. }\end{array}$ & Yes, $\mathrm{p}<0.02$ \\
\hline $3(f)$ & $\begin{array}{l}+ \text { Income } \rightarrow+\text { Desire to } \\
\text { seek the best quality } \\
\text { luxury products }\end{array}$ & $\begin{array}{l}\text { IV: Income Categories, ^DV: I want to } \\
\text { own items of top quality and I think } \\
\text { luxury items are better quality. }\end{array}$ & Yes, $\mathrm{P}<0.02$ \\
\hline
\end{tabular}

Hypothesis H1a purports that younger consumers who did not own luxury products would be more likely to aspire to own one than older consumers who similarly lacked luxury items. Results suggest that this hypothesis is partially supported $\left(\chi^{2}=4.67, \mathrm{p}<0.03\right)$, whereby the proportion of the youngest consumers willing to buy a luxury product is higher than the proportion of slightly older 
consumers ( $86 \%$ vs $55 \%$ ). Given the nature of the question, which asks for willingness to buy a luxury product if one does not own one already, the sample size for older consumers who do not already own a luxury product is naturally small. Hence, the comparison for this hypothesis is only between consumers 18-25 years of age and 25-35 years of age. Next, H1b hypothesizes that younger consumers are more likely to spend a larger proportion of their income on luxury products. For ease of exposition, we collapsed the data such that there were two categories of ages (less than 35 and over 35) and two categories of expense proportions (less than $20 \%$ of income and more than $20 \%$ of income). This is hypothesis is supported $\left(\chi^{2}=7.01, \mathrm{p}<0.00\right)$ with the data suggesting that nearly $25 \%$ of younger consumers spend more than $20 \%$ of their income on luxury products compared to only about $3 \%$ of older consumers. As expected, there seems be a larger appetite for luxury products amongst younger consumers, and recklessness with regards to how much they are willing to spend. Next, H1c suggests that the opinions of other people are more important for younger consumers than for older consumers. That is, younger consumers will be more concerned about the approval of others in the context of luxury products. The results support this hypothesis $(F(4,132)=2.27, p<0.07)$, where younger consumers believe more in the importance of opinions of other people for luxury products, compared to older consumers. Thus, the evidence suggests that susceptibility to conformity- based consumption is stronger for younger consumers. Next, H1d tests the theory that younger consumers, perhaps due to their stronger desire to consume luxury to conform, are more likely to perceive materialism in their society as more prevalent than older consumers would. The results support this hypothesis as well $(F(1,81)=3.80, p<0.06)$, where younger consumers (under 35) reported a higher mean response to the question of whether they felt Tunisians are materialistic compared to older consumers over 35 (7.58 versus 6.36). The final hypothesis pertaining to age and luxury consumption, H1e, purports that younger consumers, compared to older consumers, will be more likely to perceive that Tunisian consumers are driven primarily by conspicuous display when purchase luxury products. The results do not provide statistical support for this hypothesis. However, the means do suggest that younger consumers' perceptions that Tunisian consumers buy luxury products more for display purposes is stronger compared to the perceptions of older consumers (8.10 vs. 7.45$)$.

The next set of hypotheses use the lens of education on luxury consumption behavior and aspirations. The foundational rationale for this set of hypotheses is that the more formal education consumers have, the more likely they will be to choose luxury products for their comfort and quality, rather than merely for display purposes. It is reasonable to expect that the more formal education an individual has, the more independent their thinking is likely to become. Hence, it is likely that formal education will make consumers resist conformity-based consumption more than less educated consumers. Therefore, with a stronger desire for display and social acceptance, H2a hypothesizes that less educated consumers are likely to spend a higher proportion of their income on luxury products. The data supports this hypothesis $\left(\chi^{2}=15.42, p<0.08\right)$, whereby we found a notably larger proportion of consumers with lower educational qualifications report spending in excess of $20 \%$ of their income on luxury products, compared to consumers with higher educational qualifications $(15.4 \%$ vs $7.1 \%)$. However, a caveat is necessary for $\mathrm{H} 2 \mathrm{a}$. It is possible that this finding is actually the result of lower income. With the expectation that lower educational levels are correlated with lower incomes, this result, although statistically significant, is possibly confounded. The next hypothesis, $\mathrm{H} 2 \mathrm{~b}$, suggests that less educated consumers will have a stronger willingness to purchase luxury even if their prior levels of debt were higher than usual. The dependent variable used to test this hypothesis was derived from a question in which we asked 
respondents about their level of willingness to buy luxury products if their existing debt levels were too high. The data support this hypothesis $(\mathrm{F}(4,128)=2.91, \mathrm{p}<0.02)$, where the less educated consumers report a higher willingness to buy luxury when they had higher levels of existing debt. This question, compared to $\mathrm{H} 2 \mathrm{a}$, is less likely to be picking up the effects of income levels and to truly measure the results of education, since it tests a willingness to spend when existing debt levels are high, rather than actual expenses. Hence, $\mathrm{H} 2 \mathrm{~b}$ is a stronger test that less educated consumers have perhaps more rigid beliefs about the need for conformity and socially motivated luxury consumption, and thereby, a more reckless willingness to obtain luxury, despite having higher existing debt levels. Perhaps higher levels of education create a pragmatic, rather than reckless, approach to managing the desire for luxury products. Incidentally, post-hoc tests reveal that the differences were significant between respondents with bachelor's degrees and respondents with master's degrees or above.

The next hypotheses pertain to the relationship between educational levels and the motivations and expected outcomes of luxury consumption. The "birds' eye" perspective is that higher levels of education likely lead to more independent thinking with stronger abilities to resist conformity. In turn, such independence in thinking may foster more private and functional reasons for luxury consumption amongst more educated consumers. Less educated consumers are more likely to seek peer approval, buy things more for display and acceptance with peer and aspirant groups, and find a sense of personal achievement with luxury products. In this regard, hypothesis $2 \mathrm{c}$ purports that the higher the level of education, the higher the likelihood that chosen luxury purchases will have enduring, rather than temporary, style and will be akin to an investment. Results provide support for this hypothesis $(\mathrm{F}(4,123)=3.90, \mathrm{p}<0.00)$, in which the more highly educated consumers report buying luxury products that are enduring in value and are seen as investments, compared to less educated consumers. Similarly, H2d hypothesize that less educated consumers will be more likely to see luxury products as a means to enhance their appearance than do more educated consumers. This hypothesis is supported with the means in the expected direction $(\mathrm{F}(1,123)=4.02, \mathrm{p}<0.05)$.

The next set of hypotheses study luxury consumption from the viewpoint of income. In a manner similar to the theory discussed earlier, the rationale for luxury consumption for lower income consumers compared to higher income buyers is likely to be different. It is interesting to note that across income groups, there is no difference in the proportion of people who are in possession of luxury brands $\left(\chi^{2}=3.36, \mathrm{p}<0.33\right)$, rejecting H3a. This is very likely because the price ranges and qualities of luxury items vary widely enough to capture a variety of income groups. Such strategies make luxury brands available to large swathes of people. Furthermore, for those who did not currently own a luxury product, the willingness to purchase one is the same across income groups $\left(\chi^{2}=5.43, \mathrm{p}<0.14\right)$. In other words, nearly everybody in the population either has at least one luxury product or is willing to purchase one, regardless of income, rejecting H3b. These results are noteworthy. From a pragmatic viewpoint, one would expect that higher income would be a driver of the desire for luxury products that provide quality. That is, as income rises, it would be reasonable to expect that people may reward themselves with better quality and better functioning products. However, the results seem to contradict such a pragmatic approach to luxury. Since lower income consumers own and desire luxury, there seems to be a stronger likelihood that the reasons for that desire are beyond mere desire for higher quality. To corroborate the theory that lower income consumers are likely more susceptible to conformity or social display motivations we explore H3cH3f. 
H3c hypothesizes that consumers with lower incomes are more likely to spend a larger proportion of their income on luxury products. With the need for such products for display and social acceptance, and thus less control on which luxury products need to be purchased, it is reasonable to expect that the proportional expenditure on luxury at lower income levels is likely to be very high. That is, lower income groups probably feel a stronger need to display socially and may thus exhibit a propensity to spend proportionally more than their higher income counterparts. The self-reported data largely support this hypothesis, where lower income consumers spend a significantly larger proportion of their income on luxury products compared to higher income consumers $\left(\chi^{2}=11.18\right.$, $\mathrm{p}<0.01)$. In terms of the reasons for consumption, $\mathrm{H} 3 \mathrm{~d}$ hypothesized that lower income consumers may be more inclined to use luxury products to express accomplishment and success. The relationship between income and the question that measured luxury apparel conveying accomplishment and success was statistically significant $(\mathrm{F}(1,123)=6.00, \mathrm{p}<0.02)$. However, counter to what was expected in $\mathrm{H} 3 \mathrm{~d}$, the mean responses suggest that the higher the income, the more the tendency to use apparel to convey accomplishment and success. However, this question may be flawed in that it is possible that higher income people, as part of their professional work, are required to use certain apparel to function effectively. In other words, the validity of the question to test $\mathrm{H} 3 \mathrm{~d}$ is questionable. Next, the expectation in $\mathrm{H} 3 \mathrm{e}$, that higher income consumers would seek the best for themselves, including luxury, was tested. This hypothesis tests the expectation that as income resources grow, the desire for the better things in life, for personal reward, will be higher as well. The hypothesis was supported $(\mathrm{F}(1,123)=3.42, \mathrm{p}<0.02)$. Next, H3f tests the theory that at higher levels of income, the tendency is more to buy luxury products because they are very high in quality. This hypothesis is supported as well $(\mathrm{F}(3,123)=6.00, \mathrm{p}<0.02)$ where the highest income group seemed to desire very high quality and believed more strongly that luxury products had that level of quality. Perhaps at lower levels of income, other considerations, such as status value and peer approval play a stronger role in luxury consumption.

\section{CONCLUSIONS, LIMITATIONS AND FUTURE DIRENCTIONS}

The overarching purpose of this research was to explore the luxury product market in Tunisia. It was of particular interest to us that we understand the underlying motivations of luxury in this newly emerging market from the perspective of age, income and educational levels. To the extent such variables are relatively easy to measure, any insights into the differences luxury product consumption and motivation from these perspectives provide insights for marketing managers on product positioning, promotional decisions and pricing and for public policy makers to manage such motivations.

First, it was noteworthy to find that in every age category, more that $70 \%$ of consumers reported possessing at least one luxury product. Amongst those who did not yet own a luxury brand, all age categories admit a willingness to purchase a luxury product in the near future. Thus, in a survey done in post-revolution Tunisia, it is staggering to observe the penetration of luxury products in society and the irrefutable willingness to own luxury products. It is clear to see that this is a large market. To the extent that Tunisia is representative of many other emerging economies, the results here suggest that luxury penetration in such populations is likely to be very rapid. 
Additionally, the results also provide material for some nuanced insights. Particularly, younger consumers tend to be much more driven by their peers and seek their approval, which the results suggest is a strong reason for desire for luxury products. For younger consumers, such products are a mechanism for social acceptance and social admiration that they seek. From the seller's perspective, creating popularity and supporting larger "mass" luxury markets is likely to generate significant value for businesses marketing to younger consumers. For older consumers, who seek luxury more for the functional and quality perspective, marketing products with a quality and functionality positioning is likely to be a more successful strategy. The implications of the results exploring age and luxury consumption are far reaching. From the promotional perspective, it may be advantageous for managers to create popularity for certain mass marketed luxury products to foster conformity and social acceptance value for certain products. Such themes in advertising luxury products are likely to help in appealing to younger consumers. For older consumers, promotions and pricing based on creating a belief about quality, self-indulgence and longevity of the luxury product in question may be more valuable.

From the perspective of education, this research provides some very interesting insights as well. In particular, less educated consumers tend to spend a larger proportion of their income on luxury products. Such recklessness may allow marketers extraordinary margins for a variety of products, with less regard to quality. The more educated consumer may also yield high margins to the marketer, but is only likely to do so with a requisite return in terms of durability, functionality and investment value. There are significant implications for advertising and pricing. As an example, marketing to the less educated consumer could involve credit provision, given the propensity to spend more to acquire certain socially desirable products. From the advertising perspective, creating a sense of social acceptance and social approval with the product or service would likely make such products more attractive to younger consumers. Distribution in visible, popular locations may be desirable to capture this larger group. On the other hand, focusing on key functionality and investment value would likely succeed for products targeted to the well- educated, with more valuebased pricing and restricted distribution.

Last, from the income perspective, a similar pattern emerges. We find a higher tendency to spend a larger proportion of income on luxury for lower income consumers. Furthermore, as incomes rise, pragmatic reasons like quality, or self-reward reasons to own luxury products seem to dominate. As an extension, it is then likely that lower income consumer may be purchasing more for public display or social acceptance reasons. That is, when income is low, spending on luxury becomes one way to maintain an ability achieve social acceptance and position. Although somewhat counterintuitive, our results show that the less income one has, the stronger the desire for luxury products as a means to social display.

However, the results provide a cautionary note as well, suggesting less desirable potential outcomes. Despite the very useful prescriptions for marketers, there are significant insights in these results for public policy and society in general. To the extent younger people seek to cloak their desire for social acceptance and social position with expensive luxury products, such tendencies may lead to unsustainable habits of over spending, anxiety and family conflict. Such problems are not alien in developed economies where younger consumers have a tendency to spend disproportionately on luxury products. Excessive spending and unbridled desire for luxury for social acceptance can lead to myriad of problems in society. From the public policy perspective, perhaps prescriptive education 
on financial management, which occurs in many parts of the world, needs to include discussion and education on the perils of excessive luxury spending to achieve conformity or social position. Perhaps some instruction, discussion, and case education may help alleviate the effects of such felt peer pressure and desire for expensive luxury products. The results in this paper are a very timely reminder to public policy makers in emerging markets. Although variables such as culture may mitigate such tendencies, freedom of communication and Internet connectively act to counter such mitigation. Although we purport that avoiding the tendency toward conformity and social display through luxury in the younger, less educated or somewhat lower income groups is not entirely possible, we believe that intervention at the right venues may be of value to maintain such desire at healthy levels.

In terms of limitations of the research, we acknowledge that we were somewhat restricted by the sample that we had. Since we used Facebook users, we were somewhat limited by the profile of individuals willing to be on Facebook. There were fewer respondents in the oldest age categories, in the least educated categories and in the very highest income categories. As a result, our cells did not have perfectly balanced sizes, as one might be able to achieve with experiments and controlled samples. In future work in this area, more representative samples would be important to establish internal and external validity. Furthermore, given that this research was a broad first look at luxury consumption in Tunisia, and that we explored it from a variety of perspectives, we were limited by the length of the survey. In future work, it would be very important to use more psychometrically valid measures and perhaps probe deeper into each relationship studied.

In terms of future directions, an interesting avenue for future research may be to replicate this research using controlled experiments. Doing so will alleviate the problems due to unequal cell sizes. Furthermore, with a better sample, more nuanced interaction hypotheses can be explored. Although studying age, income, and education as independent variables impacting motivations for luxury consumption is insightful, it is important to understand that these variables also interact in their effects on luxury consumption and motivation. Further work, perhaps experimental, could develop theory in this area and take this work another step forward. Lastly, there are certainly other variables that will impact luxury product desire. Developing and testing theory in relation to such variables represents another interesting future research opportunity.

\section{REFERENCES}

Al-Momani, M. (2011). The Arab "youth quake": Implications on democratization and stability. Middle East Law and Governance, 3, 159-170.

Bishku, M. B. (2013). Is it an Arab Spring or business as usual? Recent changes in the Arab World in historical context. Journal of Third World Studies, XXX, 1, 55-77.

Dadush, U., \& Dunne, M. (2011). American and European responses to the Arab Spring: What's the big idea? The Washington Quarterly, 34, 4, 131-145.

Demirbag, M., Sahadev, S. \& Mellahi, K. (2010). Country image and consumer preference for emerging economy products: the moderating role of consumer materialism. International Marketing Review, Vol. 27, 2, 141-163.

Dziri, H. (2013). Assessing the entrepreneurial ecosystem in Tunisia. (Unpublished masters dissertation). MIT Sloan School of Management, Boston. 
Hanzaee, K. H. \& Rouhani, F. R. (2013). Investigation of the Effects of Luxury Brand Perception and Brand Preference on Purchase Intention of Luxury Products. African Journal of Business Management, 7, 18, 1778-1790.

Hofstede, G. (2001) Culture's consequences : comparing values, behaviors, institutions, and organizations across nations. Thousand Oaks, California: Sage Publications.

Hudders, L., \& Pandelaere, M. (2011).The silver lining of materialism: The impact of luxury consumption on subjective well-being. J Happiness Stud, 13, 411-437.

Husic, M. \& Cicic, M. (2009). Luxury Consumption Factors. Journal of Fashion Marketing and Management, 13, 2, 231-245.

Le Monkhouse, L., Barnes B. R., \& Stephan, U. (2012). The influence of face and group orientation on the perception of luxury goods: A four market study of East Asian consumers. International Marketing Review, 29, 6, 647-672.

Lim, W. M., Ting, D. H., Khoo, P. T. \& Wong, W. Y. (2012). Understanding consumer values and socialization - A case of luxury products. Management \& Marketing Challenges for the Knowledge Society, 7, 2, 209-220.

Maddy-Weitzman, B. (2011). Tunisia's morning after. Middle East Quarterly, 18, 3. Retrieved from http://web.ebscohost.com

Martin, J. (2012). It's not just the Arab Spring, it's the economy (stupid). Kennedy School Review, 12, 10-11.

Park, H. J., Rabolt, N. J. \& Jeon, K. S. (2008). Purchasing global luxury brands among young Korean consumers. Journal of Fashion Marketing and Management, 12, 2, 244-259.

Sanchez, A. (2009). Tunisia: trading, freedom for stability may not last - An international security perspective. Defence Studies, 9, 1, 85-92.

Souiden, N.,M'Saad, B., \& Pons, F.(2011). A cross-cultural analysis of consumers' conspicuous consumption of branded fashion accessories. Journal of International Consumer Marketing, 23, 329-343.

Soyoung, O., \& Jongeun, K. (2011). Analysis of the marketing strategy of a luxury brand and its success in selected Asian countries. The International Journal of Interdisciplinary Social Sciences, 6, 1, 239-257.

Statista, (n.d.). Retrieved from http://www.statista.com/statistics/487407/retail-value-of-theafrican-luxury-goods-market/

The World Factbook, (n.d.). Retrieved from https://www.cia.gov/library/publications/the-worldfactbook/geos/ts.html

World Bank, (n.d.). Retrieved from http://data.worldbank.org/indicator/NY.GNP.PCAP.CD?locations=TN 